\title{
THE DEVIL - THE FIRST APOPHATIC THEOLOGIAN
}

\author{
Prof. PhD. Adrian D. COVAN, \\ Lecturer, Faculty of Letters, History and Theology, West University of Timișoara, \\ ROMANIA \\ E-mail: adrian.covan@yahoo.com
}

\begin{abstract}
The first page of the invisible creation changed at the dawn of its beginnings. The crisis of authenticity has disfigured Lucifer (the opposite of existential transfiguration), the genius of shadowing light behind the wall of darkness. The fall brought, to the angelic order ,foresitter", the forever loss of its genuine state as virtuous angel. In other words, the guardian cherubim of the celestial armies wished to install an eschatology of disorder and evil in God's creation. In fact, the , morning star of dawn" had in mind to draw ,a new heaven and a new earth” where evil, dismantling and chaos were supposed to be the governing laws. His wrong understanding of beings' personal freedom will bring the scaffold of his self-petrification.
\end{abstract}

Keywords: Lucifer; falling; the tragedy of evil; sin; death; hell;

Motto: „The Devil knew God before the fall, and still sees the Glory of God, but, being impossible to heal, his nature is dark, and he sees the Glory of God as fire, hence the icon painters painting him in black, dark. The greatest apophatic theologian is the Devil, for he sees the Glory of God as both darkness and fire. The Devil knows the Holy Scripture and interprets it from his own perspective, as seen from the temptations of Christ, where he uses Scriptural passages according to his own conceptions"1.

\section{INTRODUCTION}

The Devil is not an abstract theological construct, nor is he a bizarre metaphor or a conjectural feat of imagination. To live in totalitarianism, to survive in an infernal universe these were the limits of real experience for many human beings - is the calling card of a demobilizing way of life, under the influence of pseudo-aesthetical values. We are speaking of the one who exploits human naiveté, who releases hatred, wrath, envy, resentment, into the world created by God. He is an extremely clever creature, who mobilizes, abets, intoxicates, both the elite and the masses of society with the flavor of ideology. The demon pretends to offer solutions to vital (or mortal) human matters, by canceling the distance between the Citadel of God - the place where the dough of Eternity is kneaded - and the Citadel of Man the world where the yeast of sin is leavened. The expertise of evil is the art of seduction, which consists of the amplification of the human proclivity toward grand utopias.

But the essential purpose of the presence and work of the devil in history is the usurpation of God from His position as Creator and Almighty of all that is seen and unseen,

\footnotetext{
${ }^{1}$ Ierótheos VLACHOS, Metropolitan of Nafpaktos, Dogmatica empirică după învățăturile prin viu grai ale Părintelui Ioannis Romanidis (Empirical Dogmatics according to the spoken word teachings of Father Ioannis Romanidis), vol. II, Doxologia Publishing House, Iași, 2017, p. 90.
} 
by applying unceasing pressure upon the collective mentality. Simultaneously, the devil fights against God, seeking to destroy His creation. Realizing that a direct confrontation is impossible, and that he would be defeated, no matter what, he indirectly fights against God, fighting against His creation, through all created things and beings, self-deluding with the illusion that he might be able to defeat God by defeating one of these. There is no greater joy to the devil than one not believing in his existence. As an enemy conceals their presence and aggressive intentions until the moment of the attack, so the devil is delighted by the naiveté of atheists, who deny his existence together with that of God. „Therefore, to renounce Satan does not only mean to reject a mythological being in which one no longer believes. It means rejecting this entire conception of a world filled with sufficiency and despair. Of course, Satan will not forget this rejection, this defiance, this renunciation: Blow and spit upon him! The war is declared. A true struggle begins, the real stakes of which are eternal life"2.

\section{A WONDERFUL LAND BECOMES DESOLATE: LUCIFER - THE DARING THINKER - OR „FROM THE BEGINING"3 THERE WAS NARCISSISM}

Angelology ${ }^{4}$, as an official teaching of the Church, is founded upon the testimonies of the Holy Scripture and the Holy Tradition. The same method applies to the revealed teachings about demons as fallen angels. One cannot understand the role of good angels, in service to God and man without being informed about the role of Satan, „The lord of this world", and his agents, the angels of darkness. When referring to the Holy Angels, or the Angels of God, we refer, in fact, to this entire Heavenly hierarchy composed of the nine hosts of angels of the Heavenly Army. "The purely understanding powers, meaning the bodiless angels, mostly remained in their fold, in obedience to their Maker. But many of the angels, led by the Morning Star, meaning Satan, did not stay, but fell with frightful fall, with eternal fall",. Thus, when we say „demons”, we mean the angels fallen from the Glory of God through their sin. Their fall was revealed by the Lord Jesus Christ, in Luke 10:18, when He

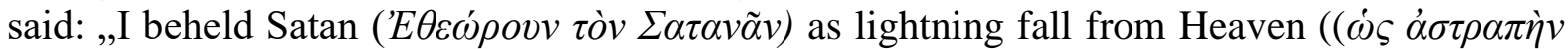

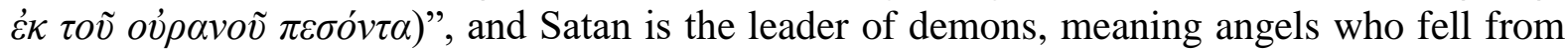
the Glory of God together with him.

The first verse of the first Biblical book provides us with the following information: „In the beginning, God made the Heavens and the Earth". Shortly afterwards, though, the situation changed dramatically. In Genesis 1:2, we find it written that „the earth was without form and void". The translation does not fully put across the meaning of the Hebrew original. The adjectives tohu and vohu, should better be rendered through the words ,desolate and void". Nevertheless, in Isaiah, 45:18, that He created it "not in vain(deserted)." The same word, tohu, is used there. If God did not create the Earth in a state that was "desolate and void", then how did the Blue Planet nevertheless end up in such a state? Partially, the answer

\footnotetext{
2 Alexander SCHMEMANN, Din apă și din Duh. Studiu liturgic al Botezului (From Water and Spirit. A Liturgical Study of Baptism), translated by Ion Buga, Symbol Publishing House, Bucharest, 1992, p. 12.

${ }^{3}$ John 3:8.

${ }^{4}$ The prophet Daniel ecstatically saw the Kingdom of God. He saw ,a fiery stream issued and came forth from

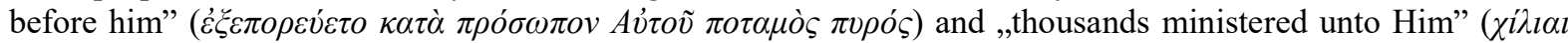

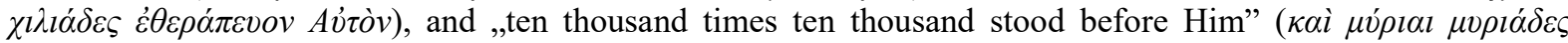

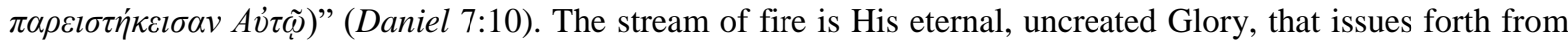
His being, whilst these thousands and ten thousand times ten thousands of heavenly creatures incessantly serving God are the powers of the Heavens of God.

5 Saint John of KRONSTADT, Despre tulburările lumii de astăzi (About the turmoil of today's world), translated by Adrian and Xenia Tănăsescu-Vlas, Sophia Publishing House, Bucharest, 2011, p. 68.
} 
is given in Genesis 1:2. The Hebrew verb haya, translated as „was”, could also be translated as „,became”, „was made” or „was turned”, (meaning „was transformed”), as it is translated in Genesis 2:8 and 19:26. The earth was not created „without form” (deserted) and void, but it became (was transformed) this way at a certain moment after its foundation. Thus, the following translation would result: „Then, the Earth became desolate and void”. God created Earth in such a bright state of beauty that ,the morning stars sang together and the sons of God shouted for joy"6. But something occurred that was meant to bring a devastating and desolate state unto the created earth. Its initial beauty was destroyed. God then remade it, turning it into a wonderful home meant for the habitation of the first human family. Thus, something happened between the first two verses of the Book of Genesis, something not recorded therein.

Entire pages of the corpus of the revelation of God soberly describe the fact that the Devil exists. Then, we find out that this creature, and the entire spiritual world, are as real as our own world. Also, the aforementioned sources describe Satan as an unbelievably powerful spiritual being, with a surprising influence over mankind. Together with his cohorts - known as devils or demons - he is frequently mentioned in the Holy Scriptures, from Genesis to Revelation. The Bible or the Holy Scripture offers much and precious information about this character. Thus, Satan, prior to becoming the prince of the Abyss, was the greatest chieftain of the angelic office. He was called Lucifer and he had his place upon the peak of perfect creation. In spite of his fall, he is closer to the nature of God than that of man, for he has no age and he cannot die. But we must not forget that the created spiritual nature of Satan entails a small number of his limits. These are only understandable when regarding him as we regard all other angels who are in a relationship with God. The superiority of spiritual beings over the material world cannot be compared whatsoever to the almighty nature of God. That of angels is executive, which means it is a relative superiority, not an absolutely creative one. The agents of the Heavens of God can use their powers and principles enrooted in their own nature by their Creator. As such, due to his bodiless nature, we see the Devil as a pure spirit, ageless, independent, and complete within himself, an entirely pure form. He is dependent upon God, but independent of all the other structures of the created area, reflecting the living brightness and the unspeakable beauty of the Living God in a unique splendor: „The Devil, before the fall, was good. But having proven carelessness and allowed himself to be overcome by despair, he fell into such great evil that he could no longer rise". Scripture also reveals that he was good. It says: I beheld Satan as lightning fall from heaven (Luke 10:18). This likening of the fall to lightning reveals his prior state the quickness with which it occurred"7.

The tragedy of sin began when the foremost of angels turned his eyes from the creator and began to admire creation ${ }^{8}$ - meaning himself: „Thine heart was lifted up because of thy beauty, thou hast corrupted thy wisdom by reason of thy brightness" ${ }^{\text {. }}$. He became prideful

\footnotetext{
${ }^{6}$ Job 38: 7.

${ }^{7}$ Saint John CHRYSOSTOMOS, Problemele vieții (The Troubles of the life), translated by Cristian Spătărelu and Daniela Filioreanu, Egumenița Publishing House, Bucharest, 2007, p. 339.

8 ,Lucifer was so beautiful in his glory that he fell in love with his own beauty. Thus, he grew proud of his brightness and intelligence. This self-pride made him wish to be like his Creator. It is because of this that he lost his inner light, thus becoming separated from God the Creator (fragment of the sermon of His Beatitude, Patriarch Daniel, spoken on November 8, the Feast of the Holy Archangels, Michael and Gabriel, at the Chapel of St. Gregory the Illuminator from Bucharest), cf. https://doxologia.ro/cuvantul-ierarhului/sfintii-ingeri-sunticoane-ale-sfinteniei-dreptatii-lui-dumnezeu.

${ }^{9}$ Ezekiel 28:17.
} 
and exalted himself, and thus the desire for conquest was born inside of him. He wanted to sit in the place of God: „How art thou fallen from heaven, O Lucifer, son of the morning! how art thou cut down to the ground, which didst weaken the nations! For thou hast said in thine heart, I will ascend into heaven, I will exalt my throne above the stars of God: I will sit also upon the mount of the congregation, in the sides of the north. I will ascend above the heights of the clouds, I will be like the Most High. Yet thou shall be brought to Hell, to the sides of the Pit" ${ }^{\prime 10}$. There are two types of narcissism: the fixation upon one's own physical beauty, and the fixation upon one's own personality. A narcissist will take themselves as a unit of measure; they themselves are their own law, not the Law of God. Basically, Lucifer started developing that sickly type of passion toward himself.

The beginning of evil within creation coincides with this conjugation: I will. Satan has ceased to submit to the Will of God and seeking out his own will. When placing another will atop the will of God, it is akin to considering that His will is not perfect. God reveals His own name by saying: „I am”. ${ }^{11}$ He does not reveal His full name to anyone. He who seeks to be himself enters a conflict with God. The sin of Lucifer consists of loving himself up to the point of excluding everything else, and this has no excuse. His sin was the sin of an evil that was born in and of itself and not induced by any outer influence. Satan fell from his high state because he did not wish to fulfill the role for which he had been created, and thus forever lost his initial state. „The essence of falling into sin is always the same: someone wants to become good by themselves; someone wants to become perfect by themselves; someone wants to become god by themselves... for he too (the devil), wanted to become a god by himself, to replace God with himself. And in his arrogance, he suddenly became a devil, utterly separated from God and entirely turned against God ${ }^{12}$. Eternal separation from God is the punishment of Lucifer and all of those who followed him and who continue to follow him, whether from the world of angels or from the kingdom of man. All of those who chose the wrong path follow Satan, taking the risk of losing God forever. In his agony and rage, the enemy seeks to destroy everything in his path, seeking to lure others into a misfortune as absolute and dark as his own turmoil: „Then, by default (the angels who allowed themselves to be lured), they were crushed and fell from their dignity and their place. At the same time, they lost the amazing, bright beauty of their countenances. They became horrible monsters, the very mention of which is frightening. In their diabolical hypostasis, there exists nothing beautiful, nothing righteous, nothing honest, nothing rational, and nothing true ${ }^{13}$.

In another few chapters of the Holy Scriptures, the Spirit of God gives us more information about the unfortunate event of the rebellion in Heaven. In the Second Epistle of Saint Apostle Peter, its author recorded several examples that describe the judgment of God, uttered upon the entire world for the wickedness committed. In chapter 2, verse 4, we read: „For if God spared not the angels that sinned, but cast them down to hell, and delivered them into chains of darkness, to be reserved unto judgment". When did these angels sin and what was their sin? The Epistle of Saint Apostle Jude, verse 6, provides the answer to the aforementioned question: „And the angels which kept not their first estate, but left their own

\footnotetext{
${ }^{10}$ Isaiah 14:12-15.

${ }^{11}$ Exodus 3:14.

12 Benedict STANCU, Cuvinte de nădejde celor fără de nădejde (Hopeful Words for the Hopeless), Sophia Publishing House, Bucharest, 2008, p. 107.

${ }^{13}$ Joseph of Vatoped Monastery, Dialoguri la Athos (Dialogues in Athos), translation and notes by Nicușor Deciu, Doxologia Publishing House, Iași, 2012, p. 71.
} 
habitation, he hath reserved in everlasting chains under darkness unto the judgment of the great day". We have seen before that upon the day of the foundation of the Earth, all of the angels rejoiced in song and praise of the Lord. It is obvious that at a later moment, some of them sinned - thus destroying the wonderful harmony and understanding in which they had rejoiced. What was the nature of their sin? They „,kept not their first estate, but left their own habitation" - they left the places and positions that God had given unto them, rebelling against the Creator of the entire Universe. The Holy Scripture does not mention the exact number of angels who fell from Heaven, but only says that those who were cast down from Heaven together with Lucifer represent the third part of the stars of heaven, meaning angels ${ }^{14}$. The place where the evil angels dwell is the air, meaning the etherical space between heaven and earth ${ }^{15}$. Other verses in Scripture attest that the angels of Satan were cast into the darkness, far from the Face of God, until the upcoming judgment ${ }^{16}$. Nevertheless, God even loves the devil. But the question of the redemption of the devil is not even posed. The problem is not whether I redeem myself if God loves me. The problem is whether I submit myself to the therapy that is required for me to reach the state of enlightenment that I need to see the Glory of God as light, not as eternal fire and the outermost darkness"17. In the previously exposed situation, the following question may be posed: was the devil aware of committing this act of spiritual suicide? Yes. Because in his case, there was no induced error of judgment; he is perfectly aware of what he is doing, and this is why his name is Satan, the accuser or the adversary. Being a creature, limited in his nature, his power is inferior to the power of God, but equal to that of other celestial leaders.

The Lord Jesus Christ claimed to have seen Satan „like lightning fell from Heaven"18. Using His Godly knowledge and experience, the Savior of the World referred to that which happened before the beginning of Time, the dramatic episode of the fall of angels. In the blinding flash that marked the cataclysm of the cosmos, two aspects are to be remarked: the light, and the zigzag movement of the one who was cast down from the glory of God. Alluding to the fall of Satan, the Lord underscores the demonic power that he has only upon this world, as well as the deceiving, deluding nature of his power. It is because of this that we find the Archangel Michael at war with the enemy. It is not the seraphs or cherubs who wage war with the darkness, for they do not oversee our world, but the archangels - the guardians of visible creation. Therefore ,there also comes a joy in Heaven on account of the fact that by fighting the good fight, the angels had - if it can be said so - rendered justice unto God, establishing a normal rapport between creature and Creator ${ }^{19}$. The name Michael, a transliteration of the Hebrew mi ka El, means ,who is (like) God”. After a more thorough analysis, one finds that the name of this archangel is mentioned in several parts of the Scripture. In these places, he is always positioned as a direct adversary to Satan. The meaning of his name attests his nature as an instrument against the devil. Michael is referred to as one of the chief princes of angels ${ }^{20}$, great prince $^{21}$ and archangel $^{22}$.

\footnotetext{
${ }^{14}$ Revelation $12: 4$ and 9.

${ }^{15}$ Ephesians 6:12.

${ }^{16}$ Isaiah 14: 12 and 15; Luke 8:31; II Peter 2:4 and Jude 1:6.

${ }^{17}$ Ierótheos VLACHOS, Metropolitan of Nafpaktos, Dogmatica empirică după învățăturile prin viu grai ale Părintelui Ioannis Romanidis (Empirical Dogmatics according to the spoken word teachings of Father Ioannis Romanidis), vol. II, Doxologia Publishing House, Iași, 2017, p. 89.

${ }^{18}$ Luke 10:18.

19 Anca MANOLACHE, Un capitol de anghelologie. Creația, natura și căderea îngerilor (A chapter of angelology. The creation, nature and fall of angels), in Studii Teologice, nr. 1-2/1955, pp. 132-133.

${ }^{20}$ Daniel 10:13.
} 
Jewish literature describes Michael as the foremost angel, the true representative of God, identifying him as the angel of Yahweh ${ }^{23}$. According to Midrash Rabbah, in the commentary to Exodus 12: 29, Michael was the angel who defended Israel against the accusations of $\operatorname{Satan}^{24}$. Nowhere is the story of the fall of Satan described more impressively than in the Godly vision of Saint Apostle John, in the book of Revelation. At the same time, one must remember that Saint John gives a symbolic account of the War in Heaven, which had begun long before the creation of the Earth and in which the Church is engaged: „And there was war in heaven: Michael and his angels fought against the dragon; and the dragon fought and his angels and prevailed not; neither was their place found any more in Heaven. And the great dragon was cast out, that old serpent, called the Devil and Satan, which deceiveth the whole world: he was cast out into the earth and his angels were cast out with him...Therefore, rejoice, ye, heavens, and ye that dwell in them. Woe to the inhabiters of the earth and of the sea, for the devil is come down unto you, having great wrath because he knoweth his time is short" 25 . His fall from Heaven produced an unquenchable wrath, for he now exerts his power over Earth alone. Satan is twice more incensed with rage, for his power is only limited to our world, and he is very aware that at the end of this age, his power to deceive man shall be no more. His time for each of us runs even shorter than that, for his skills of trapping us with the tentacles of $\sin ^{26}$ is limited to the life given unto us on Earth. Man receives the repayment of their struggle against temptations upon this Earth in eternity. The history of the fall of Satan is so dramatic that one can hardly remove their gaze from the abyss over which he reigns ${ }^{27}$, and look to Heaven, to the angels which did not fall, and directed their ardent love in its entire greatness, toward their Creator, to remain faithful to His will.

\section{THE DEVIL AND THE ARCHIPELAGO OF SIN IN INVISIBLE AND VISIBLE CREATION}

Who is Lucifer? A murderer! Why? Because, to God, sin and death are two sides of the same coin. To the devil, however, sin was a weapon; we know from the Holy Scripture that the devil committed a murder (by urging the first humans to sin, and therefore leave the sphere of theophoric virtue).

The crime committed by Lucifer does not imply physically harming the primordial couple, but urging them to sin - and by ingesting sin, they, themselves, become mortal ${ }^{28}$.

\footnotetext{
${ }^{21}$ Daniel 12:1.
}

${ }^{22}$ Jude 1:9.

${ }^{23}$ Talmud Yoma 37a, Soncino Edition, University Press, Oxford, 1935, p. 172; Midrash Rabbah, commentary on 1 la Genesis 18, and Exodus 3, 2, vol. I, Soncino Edition, Hardcover, University Press, Oxford, 1977, pp. 411, 53.

${ }^{24}$ Midrash Rabbah, p. 222.

${ }^{25}$ Revelation 12:7-15.

${ }^{26}$ „In this manner, the demons have their conversations with us in hiding, so that we might not feel where our struggle comes from. Demonic bodies (or embodiments, we might say), taking from their imaginative form various faces, colors and the shapes that they desire, they put them into our souls and spirits, and show us many things through them, they give us suggestions, they refresh memories of pleasures, faces of unholy desires, they often trouble us in our state of wake or sleep, sometimes even excite our genitals by stroking them, inciting them toward mad, unlawful erotic impulses, and they often take the warm juices inside of us to their aid (Michael PSELLUS, Dialogus de daemonum energia seu operatione, Jacques-Paul Migne, Patrologia Graeca (abreviat $P G$ ), vol. 122, Bibliotecae Cleri Universae, Paris, 1889, 848 and 861).

${ }^{27}$ Revelation 12:9.

${ }^{28}$ According to Romans 6:23. 
The poisoned angel produces the death of the soul in the most unexpected of manners, using lying as a weapon of mass destruction. The lies of the devil ${ }^{29}$, which came to be through deceit, eventually led straight to the fall of man from the state of Paradise. The venom of lies was injected the moment the old serpent told Eve that they would not die. In order to be able to persuade Eve, the devil held a speech, showing the benefits of the tree of knowledge of good and evil. In fact, we are dealing with the first advertisement, or the first advertising license of the following type: from ideologies to news. The deal with the devil or the embrace of the unnatural as a state of being has represented the common tendency in the path that mankind acceded in its path to self-development. Where in the history of mankind has such a concentration of contradictions and errors ever been seen? Some were committed via commission, others via omission, and of such a magnitude, density and intensity as the dramatic episode of the fall of man, set in the Garden of Eden? From that moment on, the divided unanimity of evil will dig out the foundation of the indomitable fortifications of good. Unfortunately, for mankind, there is no way back to the bosom of lost Paradise; their fate was sealed by themselves.

What is certain is that the initiator of disobedience instrumented sin, truly, as something lethal: „From the beginning, he was a murderer of men” ${ }^{30}$. The 8th Chant of the Matins of The Sunday of the Expulsion of Adam from Heaven reminds us of the fact that we $\sin$ because we speak to the „soul-murdering serpent $(\dot{\varepsilon} \rho \pi \varepsilon \tau \tilde{\varphi} \psi \psi v \chi 0 \varphi \theta o ́ \rho \omega)$ "31. For we

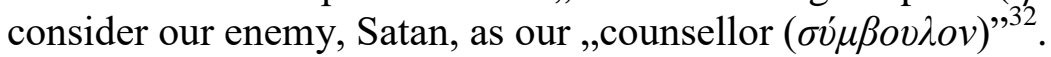

The Lord Jesus Christ referred to the unfortunate incident, to the homicide committed in the Garden of Eden, when He confronted those who were opposed to His mission and sought to kill Him on account of having called Himself the Son of God. Jesus identified the source of their motivation: „But now you seek to kill Me, a Man who has told you the truth which I heard from God. Abraham did not do this. You do the work of your father, the devil"33.

In establishing the guilt of Satan, we may take more causes into consideration. Thus, one of them is envy toward man. Satan did not want to be equal to God, but envied man, a creature so beloved by its Creator. To oppose God would have been a sacrilege and madness, but envy toward man was a more true-to-life and feasible sin. Satan, according to a theory from the $14^{\text {th }}$ century, was suffering because he had not been designated by God as the instrument of the incarnation of divine Logos, and a human being was chosen instead as a vessel of incarnation ${ }^{34}$. How did the Devil know all of this? God revealed the angels the plan of redeeming mankind by sending His Son into the world. Thus, the Devil wanted to be the Redeemer, not God. In this state, the devil may be portrayed as a jealous, disappointed lover, who was not chosen by God, in spite of his perfection, to be the second nature of Christ.

On the other hand, Apostle Paul urges his disciple, Timothy, not to anoint in the episcopal function anyone who was freshly christened, ,lest being puffed up with pride he

\footnotetext{
${ }^{29}$ „The introduction of evil, as an active principle, into the world, is an act of creation, which is analogous to the divine one. Satan was tempting Adam, whispering: you shall be as God". Thus speaking, the devil did not entirely lie: the human being, for a moment, became divine, creating evil, which contaminated everything Nicolae STEINHARDT, Jurnalul fericirii (The Journal of Happiness), Rohia Monastery Publishing House, Rohia, 2005, p. 196.

${ }^{30}$ John 8:44.

31 *** Triodul (The Triode), IBMBOR Publishing House, Bucharest, 1986, p. 92.

${ }^{32}$ Ibidem.

${ }^{33}$ John 8:41.

${ }^{34}$ „For indeed He does not give aid to angels, but He does give aid to the seed of Abraham” (Hebrews 2:16).
} 
fall into the same condemnation as the devil’,35. Here are the attitudes that can be gleaned from the aforementioned text: the pride that leads to autonomy or independence. The Old Testament portrays the devil as a created, dependent being that aspires to self-sufficiency and independence. But independence means separation from something or someone. The text of I John 3:8 states that the devil ,has sinned from the beginning”, and verse 4 defines sin as lawlessness(crime). Thus, we understand that the sin of Satan - which took the form of independence and self-sufficiency - was his desire to free himself from the „restrictions” imposed by God. Thus, when refusing to submit to the authority of the law of God, Satan showed that he wanted to live under a different set of conditions. His rebellion against the law of God denotes the fact that Satan actually rebelled against God, the author of moral law.

The three-part equation of God-man-devil is also portrayed in the Gospel scene of the healing of the two demoniacs from Gadara. Unlike atheists, the devil believes in God and fears Him: „What have we to do with You, Jesus, You Son of God the Most High? Have You come here to torment us before the time?" shouted the demons from the two Gadarenes, proving that they knew of and believed in the day of judgment, and that the present day and this illusion and temptation-fraught world were their time and their place. Within this period, they are trying to win over as many souls as possible.

His acerbic hatred toward $\operatorname{man}^{36}$ is reflected in the scene of the temptation of the righteous Job. The Book of Job seeks to answer the following question: how is something like this possible? „From the grand inaugural scene, Satan, the accuser, demands a radical trial of the fidelity of Job. And his demand is fulfilled. At first sight, the various temptations Job is subjected to seem to focus only on his worldly possessions and his physical integrity, but the speeches of his friends and even clearer from the chastisement of his wife, one can understand what these sorrows must provoke Job to do: to rebel against God. This is the very thing that his accuser predicts ${ }^{37}$.

Satan is permanently driven against the Gospel, as it is obvious during the entire public activity of our Lord Jesus Christ ${ }^{38}$. He sometimes worked through the disciples of our Savior, as in the moment apostle Peter rejected the solution of crucifixion for our Lord, and was then

\footnotetext{
${ }^{35}$ I Timothy 3:6.

${ }^{36}$ Demons, like angels, have the capacity of making astounding changes in the material world. In the Book of $J o b, 1: 13-19$, we read about how the fire sent by the devil consumed the flocks of sheep and the shepherds. Also here, we find out that a powerful gust of wind started as a result of the action of an unholy spirit, and the house in which the sons and daughters of Job were gathered collapsed unto them, claiming their lives. The book of Tobit mentions the demon Asmodeus, who killed the seven men Sarah was married to, one by one (Tobit 3:8). The action of demons upon matter, as well as other characteristics of spirits are revealed in the book of Judges. An angel revealed himself to Gideon, the future judge of Israel, and when he prepared his offering, ,the angel of the Lord put forth the end of the staff that was in his hand and touched the flesh and the unleavened cakes; and there rose up fire from under the rock and consumed the flesh and the unleavened cakes; then the angel of the Lord departed from him" (Judges 6:21). We observe that immaterial spirits were created from the very beginning from a substance that is more subtle than that which human beings are made of, and endowed with powers that allow them to exert a considerable influence upon the whole creation. Furthermore, they possess vast knowledge about the organization of matter and the laws of the visible world, having means that give them the possibility of influencing these laws. But the sensorial capacities that demons possess disorganise and destroy.

${ }^{37}$ Gabriel BUNGE, Gastrimargia sau nebunia pântecelui — știința și învățătura Părinților pustiei despre mâncat și postit plecând de la scrierile avvei Evagrie Ponticul (Gastrimarchy or the madness of the stomachthe science and teachings of the Holy Fathers of the Desert), translated by Ioan Moga, Deisis Publishing House, Sibiu, 2014, p. 59.

38 See Colin BROWN, The New International Dictionary of New Testament Theology, vol. 3, Zondervan Publishing House, Reprint edition (1979), pp. 468-473.
} 
chastised: „Get thee behind me, Satan!”39. The wicked one had other traps set for the oldest of the Apostles, but the Lord prayed for him ${ }^{40}$. All of this reached a peak in the last days of the earthly life of our Lord. The work of Judas is described as being a work of the evil one. At the Last Supper, Satan entered the person of the traitor ${ }^{41}$, „having put into the heart of Judas Iscariot, Simon's son, to betray Him" ${ }^{42}$. Thinking of His frightening trials, Jesus states: „The prince of the world cometh"

Satan continues to tempt people ${ }^{44}$. We read about his pernicious work, through a socalled believer, Ananias ${ }^{45}$, then through the sorcerer Elymas ${ }^{46}$, and last, but not least, through the acts of those who live where ,the seat of Satan" ${ }^{47}$ lies. The Devil impeded the work of Christian missionaries ${ }^{48}$. He steals the good seed sown into the hearts of people ${ }^{49}$ and sows the tares of lies in the ground of this world ${ }^{50}$. By countering the devastating actions of the devil, through obeisance to our Lord Jesus Christ, through His suffering, death and resurrection, God offered everyone the only means of atonement for the sins of mankind. Thus, those who, through grace, good deeds and faith, accept to construct the edifice of their redemption, shall gain eternal life ${ }^{51}$. At the same time, all of creation may better understand the boundless and peerless love of the Maker of all. In His endless love and mercy, God made it so that Christ, who knew not sin, be made sin for our sake, so that through Him we may inherit the holiness of God.

\section{CONCLUSIONS}

To conclude with, through His death upon the cross, the Anointed One of God has triumphed over the forces of evil; He who compelled demonic spirits during His earthly ministry shattered their power and made their final condemnation certain. The victory of the Lord Jesus Christ is the source of our triumph over the forces of evil which are trying to rule over us. If we join with Him in peace and joy, having the certainty of His love, we truly feel the restoring, sanctifying work of the Holy Spirit dwelling within us. As we ceaselessly consecrate ourselves to life in Christ, we free ourselves from the burden of deeds inspired by spirits of wickedness, no longer living in darkness and abandoning ignorance and a meaningless life.

\footnotetext{
${ }^{39}$ Matthew 16:23.

40 „What could our enemy, the devil, not have done if the Lord were not with us? Listen to what Christ says unto Simon Peter: Simon, Simon, behold, Satan hath desired to have you, that sift you like wheat, but I have prayed for you, that thy faith not fail (Luke 22:31). For the beast is wicked and ravenous, and were it not kept at bay, it would upend everything" (Saint John CHRYSOSTOMOS, Diavolul și magia, culegere de texte patristice și traducerea lor în neogreacă de Ieromonahul Benedict Aghioritul (The devil and magic: A Collection of patristic texts and their translation from New Greek by Hieromonk Benedict Hagiorite), translated by Zenaida Anamaria Luca, Agaton Publishing House, Făgăraș, 2012, p. 59.

${ }^{41}$ Luke 22:3 and John 13:27.

${ }^{42}$ John 13:2.

${ }^{43}$ John 14:30.

${ }^{44}$ See I Corinthians 7:8.

${ }^{45}$ Acts 5:3.

${ }^{46}$ Acts 13:10.

${ }^{47}$ Revelation $2: 13$.

${ }^{48}$ I Thessalonians 2:18.

${ }^{49}$ Mark 4:15.

${ }^{50}$ Matthew 13:38.

51 Alin Cristian Scridon, Memoriile unui protopop uitat: Simion Cornea și realitățile ecleziale din anii 19241928 (Memoirs of a forgotten archpriest: Simion Cornea and the ecclesial realities of 1924-1928), in Altarul Banatului, Anul XXVIII (LXVII) serie nouă, nr. 10-12/2017, octombrie-decembrie, Timișoara, p. 125.
} 


\section{BIBLIOGRAPHY:}

[1] Biblia sau Sfânta Scriptură (The Bible or Holy Scripture), IBMBOR Publishing House, Bucharest, 1968.

[2] Triodul (The Triode), IBMBOR Publishing House, Bucharest, 1986.

[3] Midrash Rabbah, vol. I, Soncino Edition, Hardcover, University Press, Oxford, 1977.

[4] Talmud, Soncino Edition, University Press, Oxford, 1935.

[5] Saint John CHRYSOSTOMOS, Problemele vietii (The Troubles of the life), translated by Cristian Spătărelu and Daniela Filioreanu, Egumenița Publishing House, Bucharest, 2007.

[6] Saint John CHRYSOSTOMOS, Diavolul și magia, culegere de texte patristice și traducerea lor în neogreacă de Ieromonahul Benedict Aghioritul (The Devil and Magic: A Collection of patristic texts and their translation from New Greek by Hieromonk Benedict Hagiorite), translated by Zenaida Anamaria Luca, Agaton Publishing House, Făgăraș, 2012.

[7] Saint John of KRONSTADT, Despre tulburările lumii de astăzi (About the turmoil of today's world), translated by Adrian and Xenia Tănăsescu-Vlas, Sophia Publishing House, Bucharest, 2011.

[8] Joseph of Vatoped Monastery, Dialoguri la Athos (Dialogues in Athos), translation and notes by Nicuşor Deciu, Doxologia Publishing House, Iași, 2012.

[9] Psellus, Michael, Dialogus de daemonum energia seu operatione, Jacques-Paul Migne, Patrologia Graeca, vol. 122, Bibliotecae Cleri Universae, Paris, 1889.

[10] Brown, Colin, The New International Dictionary of New Testament Theology, vol. 3, Zondervan Publishing House, Reprint edition (1979).

[11] Bunge, Gabriel, Gastrimargia sau nebunia pântecelui - știința și învățătura Părinților pustiei despre mâncat și postit plecând de la scrierile avvei Evagrie Ponticul (Gastrimarchy or the madness of the stomach - the science and teachings of the Holy Fathers of the Desert), translated by Ioan Moga, Deisis Publishing House, Sibiu, 2014.

[12] Manolache, Anca, Un capitol de anghelologie. Creația, natura şi căderea îngerilor (A chapter of angelology. The creation, nature and fall of angels), in Studii Teologice, nr. 1-2/1955.

[13] Schmemann, Alexander, Din apă și din Duh. Studiu liturgic al Botezului (From Water and Spirit. A Liturgical Study of Baptism), translated by Ion Buga, Symbol Publishing House, Bucharest, 1992.

[14] Scridon, Alin Cristian, Memoriile unui protopop uitat: Simion Cornea și realitățile ecleziale din anii 1924-1928 (Memoirs of a forgotten archpriest: Simion Cornea and the ecclesial realities of 1924-1928), in Altarul Banatului, Anul XXVIII (LXVII) serie nouă, nr. 10-12/2017, octombriedecembrie, Timișoara.

[15] Stancu, Benedict, Cuvinte de nădejde celor fără de nădejde (Hopeful Words for the Hopeless), Sophia Publishing House, Bucharest, 2008.

[16] Steinhardt, Nicolae, Jurnalul fericirii (The Journal of Happiness), Rohia Monastery Publishing House, Rohia, 2005.

[17] Vlachos, Ierótheos, Metropolitan of Nafpaktos, Dogmatica empirică după învățăturile prin viu grai ale Părintelui Ioannis Romanidis (Empirical Dogmatics according to the spoken word teachings of Father Ioannis Romanidis), vol. II, Doxologia Publishing House, Iași, 2017. 